\title{
Oil-Water-Gas Three-Phase Separation in Multitube T-Junction Separators
}

\author{
Lele Yang ${ }^{1,2} \mathbb{E}$, Jing Wang ${ }^{1,2}$, Yong Ma ${ }^{1,2, *}$, Sen Liu ${ }^{1}$, Jun Tang ${ }^{3}$ and Yongbing Zhu ${ }^{3}$ \\ 1 School of Marine Engineering and Technology, Sun Yat-sen University, Guangzhou 510275, China; \\ yanglele@mail.sysu.edu.cn (L.Y.); wangjing27@mail.sysu.edu.cn (J.W.); lius35@mail2.sysu.edu.cn (S.L.) \\ 2 Southern Marine Science and Engineering Guangdong Laboratory (Zhuhai), Zhuhai 519000, China \\ 3 Guangzhou Marine Geological Survey, Guangdong 510075, China; tangjun@hydz.cn (J.T.); \\ zhuyongbing@hydz.cn (Y.Z.) \\ * Correspondence: mayong3@mail.sysu.edu.cn; Tel.: +86-155-4504-1300
}

Received: 21 October 2019; Accepted: 15 December 2019; Published: 16 December 2019

\begin{abstract}
Multitube T-junctions can be used as an oil-water-gas pre-separator in the oil and gas industry. In this paper, the mixture model, coupled with the $k-\varepsilon$ turbulent model, was applied for a simulation of the oil-water-gas three-phase flow characteristics in the multitube T-junction separator. The oil droplet size ranged from 1 to $4 \mathrm{~mm}$. The water content ranged from $5 \%$ to $20 \%$ and the gas content from $3 \%$ to $25 \%$. According to the phase separation results for different droplet sizes, it was found that, as the oil droplet size increased, the water content at the water outlet initially increased and then tended to be stable. Therefore, it was necessary to increase the oil droplet size through corresponding measures before flowing into the T-junction for separation. For the separator with an inner diameter of $50 \mathrm{~mm}$, the oil content at the inlet had a great influence on the water-oil separation performance, and the water-oil separation performance was obviously improved as the oil content decreased. Owing to increased residence time, the oil content had little influence on the water-oil separation performance when the separator with an inner diameter of $100 \mathrm{~mm}$ was applied. Moreover, for the separator with an inner diameter of $100 \mathrm{~mm}$, the oil content had little influence on the degassing effect, and more than $90 \%$ of the gas could be discharged from the gas outlet. The separation performance of the multitube T-junction separator became worse as the inlet gas content increased.
\end{abstract}

Keywords: oil-water-gas separation; multitube T-junction; oil droplet; oil content; gas content

\section{Introduction}

The separation of oil-water-gas mixtures, including oily wastewater, oil spills, and oil/gas content, has attracted global interest. Various techniques such as gravity separation, membranes separation, and coagulation and oil absorbing processes have been employed for further treatment of these mixtures [1-3]. However, these approaches no longer meet the application requirements in terms of treatment capacity and separation efficiency [4]. The T-junction separator, which mainly uses gravity and expansion, can serve as a solution. The T-junction separator exhibits high performance and has a relatively small size, owing to its short fluid residence durations.

In fact, whether onshore or offshore oil fields, oil and gas resources are generally transported through complex pipe network systems. A large number of T-junction tubes exist in these complex transportation networks [5]. When single phases occur, such as crude oil or natural gas flow in the pipeline, uneven flow distribution will occur after passing through these T-junction tubes under different incoming flow and operating conditions [6]. When multiphase media such as crude oil and water, natural gas, and condensate, or oil, gas, and water coexist in the pipeline, the flow condition 
will become more complicated, and the phase maldistribution will occur. If the degree of this phase maldistribution can be enhanced, T-junction tubes can be used as an oil-water-gas pre-separator in the oil and gas industry [7].

Seeger et al. [8] tested the phase separation of air-water and steam-water in T-junction tubes. By fitting a large number of experimental data, they obtained the prediction formula of phase separation for different branch angles. Similarly, Chisholm [9] and Saba and Lahey [10] obtained the empirical formula of the pressure drop by fitting experimental data. Reimann and Seeger [11] simplified these empirical models, and compared them with those previously published and their new models with experimental results. The agreement was good for the horizontal and vertical downward branches; however, no model satisfactorily predicts the pressure drop in the upward branch flow. Baker et al. [12] investigated the transient effects in gas-liquid phase separation in a pair of T-junctions. The separation system underwent a rapid global change in the liquid hold-up when the gas inlet superficial velocity changed. For changes in the inlet liquid superficial velocity, no unexpected flow regimes were observed. He et al. [13] showed that the gas phase was easier to flow out of the branch pipe under slug slow. The slug flow in T-junction tubes is rather unstable, it is difficult to describe it via a theoretical model. Therefore, the separation results of T-junction tubes under slug flow are mainly predicted by fitting the empirical correlation $[8,14]$.

Besides the empirical model, many appearance models have been proposed, based on theoretical analysis. In order to predict the phase separation in T-junction tubes, Hwang et al. [15] established a prediction model of phase separation based on the idea of dividing streamlines. However, this model is only applicable to the horizontal T-junction tubes. Based on this idea, Penmatcha et al. [16] deduced the momentum equation, and considered the gravity action of the liquid, which contributed to expanding the application scope of this model and enabled it to predict the phase separation results in vertical T-junction tubes. Hart et al. [17] proposed the so-called double-streamline model based on the extended Bernoulli equation. However, the hypothesis of the thin liquid film was used in the derivation process of the double-streamline model, and thus the model was only applicable in the conditions where the liquid hold-up at the inlet was less than 0.06. On the basis of the double-streamline model, Ottens [18] developed a new model to predict the instantaneous characteristics of gas-liquid two-phase flow, and the steady-state and time-dependent dynamic values predicted by the model were in good agreement with the on-line measured experimental data.

Through a literature review, it is found that many efforts have concentrated on gas-liquid separation in T-junctions, compared with very limited work concentrated on the liquid-liquid separation. Yang et al. [19] first investigated the phase split of water-kerosene in T-junctions by experimental tests and developed a simplified model for predicting the separation results. Through further experimental investigation, Yang and Azzopardi [20] found the degree of phase maldistribution at a T-junction was not very great and preferential emergence of either phase from the side-arm depended on the flow rates of the two-phases.

Most previous research studied the phase separation in T-junction tubes via experimental tests, and mainly studied gas-liquid or oil-water separation, respectively. In addition, nearly all the models are either wholly empirical or based on flow analysis that still relies on empirical correlations, which renders the predictability of phase separation largely dependent on the specific experiments. Today, the prediction of phase maldistribution at a pipe junction remains a serious concern [21]. Some scholars have indicated that increasing the number of T-junctions can improve the efficiency of phase separation [22,23]. In this study, combined with the mixture model and the standard $k-\varepsilon$ model, a numerical model, suitable for simulating the three-phase separation of oil-water-gas in the multitube T-junction separator, was established. The effects of oil droplet size and oil content on the oil-water-gas separation performance of multitube T-junction separators have been studied. 


\section{Numerical Model}

\subsection{Geometry Model and Mesh Generation}

The multitube T-junction separator consists of three layers of horizontal pipes. The horizontal pipes of each layer are connected by inclined vertical pipes. Under the effect of gravity, the gas phase rises to the upper horizontal pipe, the oil phase rises to the middle horizontal pipe, and the water phase sinks to the lower horizontal pipe, finally realizing the oil-water-gas three-phase separation. Therefore, the outlet of the upper horizontal pipe is the air outlet, the middle one is the oil outlet, and the lower one is the water outlet. Two types of multitube T-junction separators were applied, with an inner diameter of 50 or $100 \mathrm{~mm}$. The geometry model of the multitube T-junction separator is shown in Figure 1. There are five lower inclined pipes and five upper inclined pipes. The spacing between inclined pipes is $1000 \mathrm{~mm}$, and the inclination angle is $60^{\circ}$.

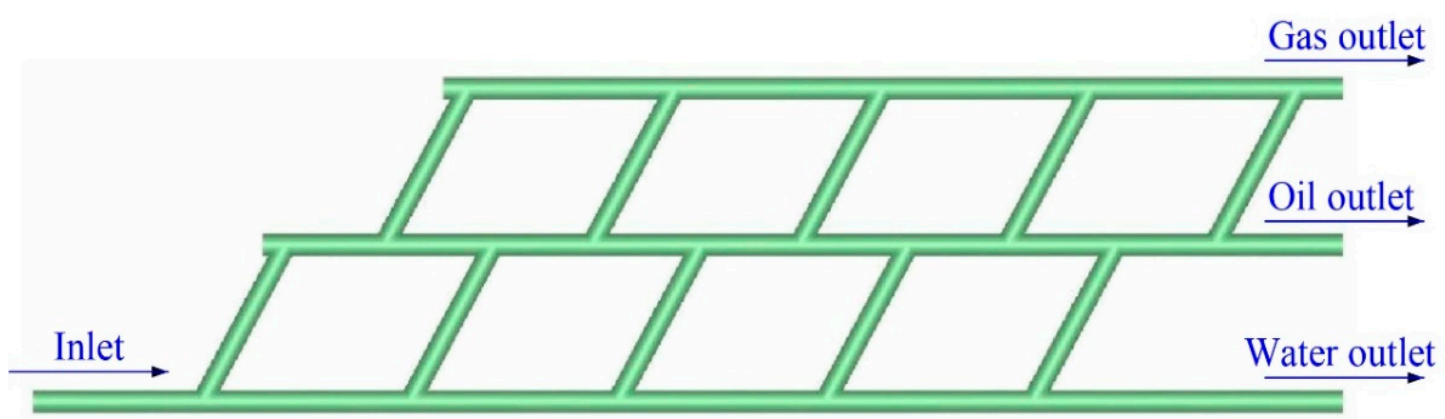

Figure 1. Geometry model of multitube T-junction separator.

To improve the calculation accuracy, the grid is regionally generated, as shown in Figure 2. Due to the flow complexity in the T-junctions, compact tetrahedral cells are generated in T-junctions blocks, while hexahedral cells are produced in the other blocks by Cooper. The distortion rate of the grid is controlled within 0.8 , and the calculation accuracy is within $10^{-3}$.

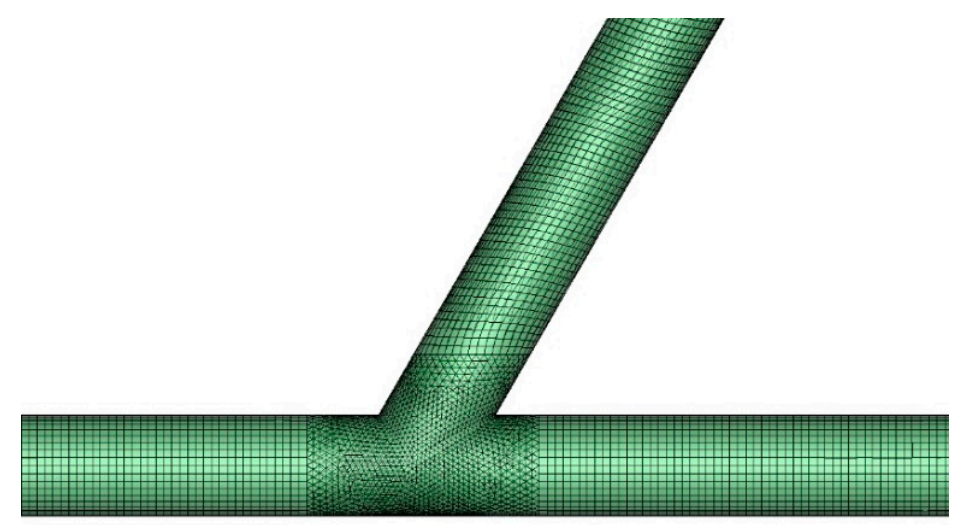

Figure 2. Mesh generation of multitube T-junction separator.

\subsection{Transport Equations and Turbulent Model}

The mixture model, a simplified multiphase flow model, is used to simulate the multiphase flow with different velocities and assumes local equilibrium on a short spatial scale [24]. It is also used to simulate the isotropic multiphase flow with strong coupling and the multiphase flow with the same velocity. Typical applications of the mixture model include sedimentation, cyclone separators, and bubble flows with low gas volume fractions. By analyzing the law of the gas-liquid flow in the T-junction tubes, the mixture model can also be used to simulate the hydrodynamic characteristics of the multiphase fluid in the T-junction tubes. 
In Fluent, the mixture model uses the concept of slip velocity, allowing the phases to move at different speeds [25]. The continuity equation of the mixture model is:

$$
\frac{\partial}{\partial t}\left(\rho_{m}\right)+\nabla \cdot\left(\rho_{m} \vec{v}_{m}\right)=\dot{m}
$$

where $\dot{m}$ is the mass transfer of the mass source, $\vec{v}_{m}$ is the average mass velocity, and $\rho_{m}$ is the mixed density.

$$
\begin{gathered}
\vec{v}_{m}=\frac{\sum_{k=1}^{n} \alpha_{k} \rho_{k} \vec{v}_{k}}{\rho_{m}} \\
\rho_{m}=\sum_{k=1}^{n} \alpha_{k} \rho_{k}
\end{gathered}
$$

The momentum equation of the mixture model can be obtained by summing the momentum equations of each phase, which can be expressed as:

$$
\frac{\partial}{\partial t}\left(\rho_{m} \vec{v}_{m}\right)+\nabla \cdot\left(\rho_{m} \vec{v}_{m} \vec{v}_{m}\right)=-\nabla p+\nabla \cdot\left[\mu_{m}\left(\nabla \vec{v}_{m}+\nabla \vec{v}_{m}^{T}\right)\right]+\rho_{m} \vec{g}+\vec{F}+\nabla \cdot\left(\sum_{k=1}^{n} \alpha_{k} \rho_{k} \vec{v}_{d r, k} \vec{v}_{d r, k}\right)
$$

where $\vec{F}$ is the body force, $\mu_{m}$ is the mixing viscosity, and $\vec{v}_{d r, k}$ is the drift velocity of the second phase.

$$
\begin{gathered}
\mu_{m}=\sum_{k=1}^{n} \alpha_{k} \mu_{k} \\
\vec{v}_{d r, k}=\vec{v}_{k}-\vec{v}_{m}
\end{gathered}
$$

The relative velocity is defined as:

$$
\vec{v}_{q p}=\vec{v}_{p}-\vec{v}_{q}
$$

The drift velocity and relative velocity is related as:

$$
\vec{v}_{d r, p}=\vec{v}_{q p}-\sum_{k=1}^{n} \frac{\alpha_{k} \rho_{k}}{\rho_{m}} \vec{v}_{q k}
$$

The mixture model uses the algebraic slip formula. The basic assumption of the algebraic slip formula is to specify the algebraic relationship of the relative velocity. The local equilibrium between phases should be achieved on a short spatial length scale. The relative velocity is defined as:

$$
\vec{v}_{q p}=\tau_{q p} \vec{\alpha}
$$

where $\tau_{q p}$ is the relaxation time of the particle, and $\vec{\alpha}$ is the acceleration of the second phase.

According to the Manninen theory [26], $\tau_{q p}$ can be given as:

$$
\tau_{q p}=\frac{\left(\rho_{m}-\rho_{p}\right) d_{p}^{2}}{18 \mu_{q} f_{\text {drag }}}
$$

where $d_{p}$ is the radius of the second phase particle, and the drag coefficient refers to the study of Schiller and Naumann [27].

$$
f_{\text {drag }}=\left\{\begin{array}{l}
1+0.15 R e^{0.687} \\
0.0183 R e
\end{array}\right.
$$


The form of acceleration is expressed as:

$$
\vec{\alpha}=\vec{g}-\left(\vec{v}_{m} \cdot \nabla \vec{v}_{m}\right)-\frac{\partial \vec{v}_{m}}{\partial t}
$$

The volume fraction equation of the second phase is given as:

$$
\frac{\partial}{\partial t}\left(\alpha_{p} \rho_{p}\right)+\nabla \cdot\left(\alpha_{p} \rho_{p} \vec{v}_{m}\right)=-\nabla \cdot\left(\alpha_{p} \rho_{p} \vec{v}_{d r, p}\right)
$$

While the flow in the multitube T-junction separator is turbulent, the flow is relatively stable. Therefore, the standard $k-\varepsilon$ model is selected to simulate the turbulent motion, and the equation is expressed as:

$$
\begin{gathered}
\frac{\partial}{\partial t}\left(\rho_{m} k\right)+\nabla \cdot\left(\rho_{m} \vec{v}_{m} k\right)=\nabla \cdot\left(\frac{\mu_{t, m}}{\sigma_{k}} \nabla k\right)+G_{k, m}-\rho_{m} \varepsilon \\
\frac{\partial}{\partial t}\left(\rho_{m} \varepsilon\right)+\nabla \cdot\left(\rho_{m} \vec{v}_{m} \varepsilon\right)=\nabla \cdot\left(\frac{\mu_{t, m}}{\sigma_{\varepsilon}} \nabla \varepsilon\right)+\frac{\varepsilon}{k}\left(C_{1 \varepsilon} G_{k, m}-C_{2 \varepsilon} \rho_{m} \varepsilon\right)
\end{gathered}
$$

\subsection{Boundary Conditions}

In this study, water, air, and oil were used as the test fluids, and their physical properties are listed in Table 1. A uniform velocity profile was adopted at the inlet boundary. Taking the practical working conditions of Bohai Oilfield in China as a reference, the inlet water-oil mixture flow rate was set as $20 \mathrm{~m}^{3} / \mathrm{h}$ for the multitube T-junction separator with an inner diameter of $50 \mathrm{~mm}$, and the inlet water-oil mixture flow rate was set as $50 \mathrm{~m}^{3} / \mathrm{h}$ for the multitube T-junction separators with an inner diameter of $100 \mathrm{~mm}$. A free outlet boundary was employed at both outlets. Near-wall flow was resolved by the standard wall function. The flow rate at each outlet was consistent with the flow rate of the corresponding phase at the inlet.

Table 1. Physical parameters of water, air, and oil $\left(20^{\circ} \mathrm{C}\right)$.

\begin{tabular}{ccc}
\hline Fluid & Density $\left(\mathbf{k g} / \mathbf{m}^{\mathbf{3}}\right)$ & Viscosity $(\mathbf{m p a} \cdot \mathbf{s})$ \\
\hline Water & 998.2 & 1.003 \\
Air & 1.225 & 0.01789 \\
Oil & 840 & 31 \\
\hline
\end{tabular}

The turbulent flow at the inlet was characterized by hydraulic diameter and turbulent intensity. In this study, the hydraulic diameter $D_{H}$ was equal to the inlet pipe diameter. The turbulent intensity was calculated as:

$$
\begin{gathered}
I=u^{\prime} / \bar{u}=0.16\left(\operatorname{Re}_{D_{H}}\right)^{-1 / 8} \\
\operatorname{Re}_{D_{H}}=\frac{D_{H} u_{m} \rho_{m}}{\mu_{m}}
\end{gathered}
$$

\subsection{Verification of Simulation}

The validation was made by comparing the results obtained from the simulation with the experimental data obtained by Yang et al. [5]. They developed an experimental study on gas and liquid separation at T-junction tubes. The experimental separator consisted of four connecting tubes, and the angle between the straight arm and the lateral arm was $60^{\circ}$, and the pipe diameter was $50 \mathrm{~mm}$. Air and water were chosen as the test fluids. In Figure 3, the mixture flow rate was $4.53 \mathrm{~m}^{3} / \mathrm{h}$ and the gas content was 0.26 in case \#1, and the mixture flow rate was $8.13 \mathrm{~m}^{3} / \mathrm{h}$ and the gas fraction was 0.30 in case \#2. The split ratio was defined as the ratio of the mixture flow rate at the gas outlet to that at the inlet. As can be seen, the variation of the gas content at the gas outlet with the split ratio obtained by 
numerical simulation was in agreement with the experimental results. With the increase in the split ratio, the gas content at the gas outlet gradually decreased. Therefore, the numerical model developed in this study was adequate to predict the separation behavior and hydrodynamic characteristics in the multitube T-junction separator.

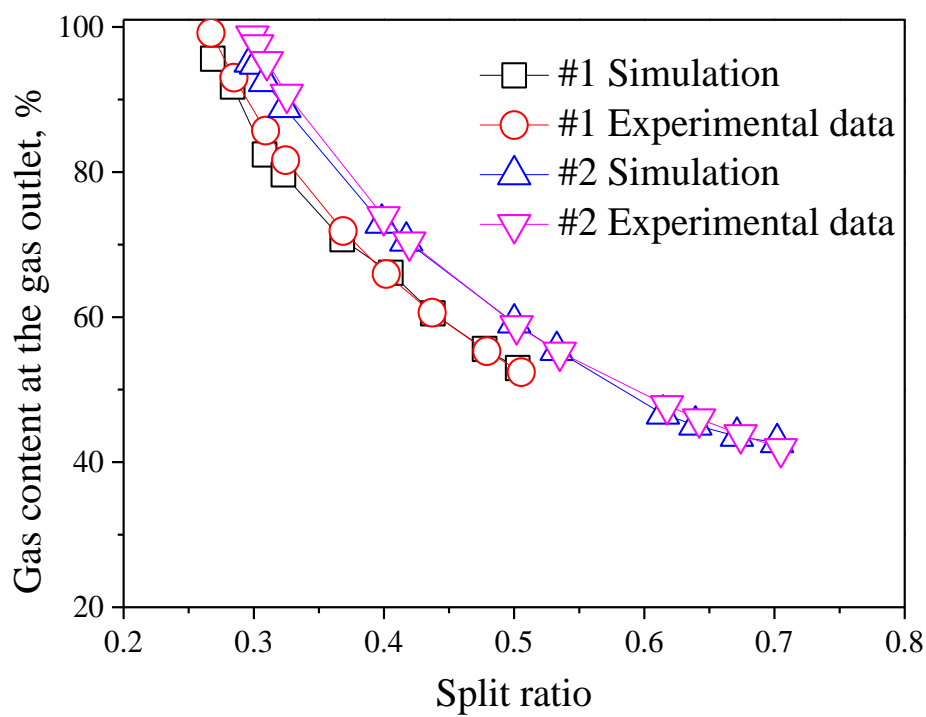

Figure 3. Comparison between simulations and experimental data by Yang et al. [5].

\section{Results and Discussions}

\subsection{Effect of the Oil Droplet Size on the Separation Performance}

Table 2 shows the effect of the oil droplet size on the separation performance of multitube T-junction separators with inner diameters of $50 \mathrm{~mm}$ under inlet $20 \mathrm{~m}^{3} / \mathrm{h}$ flow rates. The content of each phase is based on volume. Figures 4-7 show the corresponding phase distribution in the separator with oil droplet sizes of 1 and $2 \mathrm{~mm}$. In the figures, blue represents low content of the corresponding phase and red represents high content of the corresponding phase. When the oil droplet size increased from 1 to $2 \mathrm{~mm}$, the water content at the water outlet increased from $94.91 \%$ to $97.80 \%$, and the water content at the oil outlet changed from $29.76 \%$ to $22.74 \%$. However, the separation performance changed slightly for the oil droplet size of 2,3, and $4 \mathrm{~mm}$. When the oil droplet size increased, the gas content at the gas outlet increased rapidly, which meant that the degassing effect became better. As there were usually many elbows in the conveying pipeline, it is easy to cause emulsification when the oil, gas, and water flowed in it, which made the oil droplet size smaller [28]. Therefore, it is necessary to increase the oil droplet size through some measures before flowing into the T-junction for separation. For example, chemical agents can be added for demulsification before separation.

Table 2. Influence of the oil droplet size on the separation performance under inlet $20 \mathrm{~m}^{3} / \mathrm{h}$ flow rate.

\begin{tabular}{cccccccccc}
\hline $\begin{array}{c}\text { Oil } \\
\text { Droplet } \\
\text { Size } \\
(\mathbf{m m})\end{array}$ & $\begin{array}{c}\text { Water } \\
\text { Flow } \\
\text { Rate } \\
\left(\mathbf{m}^{\mathbf{3}} \mathbf{h}\right)\end{array}$ & $\begin{array}{c}\text { Oil } \\
\text { Flow } \\
\text { Rate } \\
\left(\mathbf{m}^{\mathbf{3}} / \mathbf{h}\right)\end{array}$ & $\begin{array}{c}\text { Gas } \\
\text { Flow } \\
\text { Rate } \\
\left(\mathbf{m}^{\mathbf{3}} / \mathbf{h}\right)\end{array}$ & $\begin{array}{c}\text { Water } \\
\text { Content at } \\
\text { the Water } \\
\text { Outlet }\end{array}$ & $\begin{array}{c}\text { Gas } \\
\text { Content at } \\
\text { the Water } \\
\text { Outlet }\end{array}$ & $\begin{array}{c}\text { Water } \\
\text { Content } \\
\text { at the Oil } \\
\text { Outlet }\end{array}$ & $\begin{array}{c}\text { Gas } \\
\text { Content } \\
\text { at the Oil } \\
\text { Outlet }\end{array}$ & $\begin{array}{c}\text { Gas } \\
\text { Content at } \\
\text { the Gas } \\
\text { Outlet }\end{array}$ & $\begin{array}{c}\text { Water } \\
\text { Content at } \\
\text { the Gas } \\
\text { Outlet }\end{array}$ \\
\hline 4 & 16.9 & 3.1 & 0.62 & 0.9967 & 0.0087 & 0.2274 & 0.0313 & 0.9080 & 0.0920 \\
3 & 16.9 & 3.1 & 0.62 & 0.9816 & 0.0105 & 0.2385 & 0.0210 & 0.8965 & 0.1035 \\
2 & 16.9 & 3.1 & 0.62 & 0.9780 & 0.0034 & 0.2431 & 0.0068 & 0.5933 & 0.0697 \\
1 & 16.9 & 3.1 & 0.62 & 0.9491 & 0.0014 & 0.2976 & 0.0014 & 0.4098 & 0.2318 \\
\hline
\end{tabular}




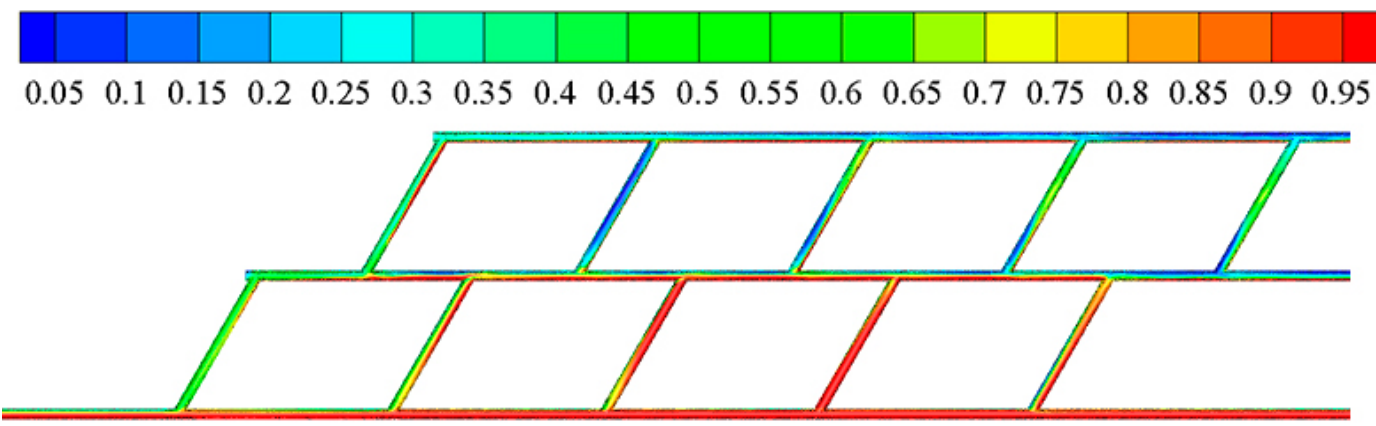

Figure 4. Water content distribution for the oil droplet size of $1 \mathrm{~mm}$ under inlet $20 \mathrm{~m}^{3} / \mathrm{h}$ flow rate.

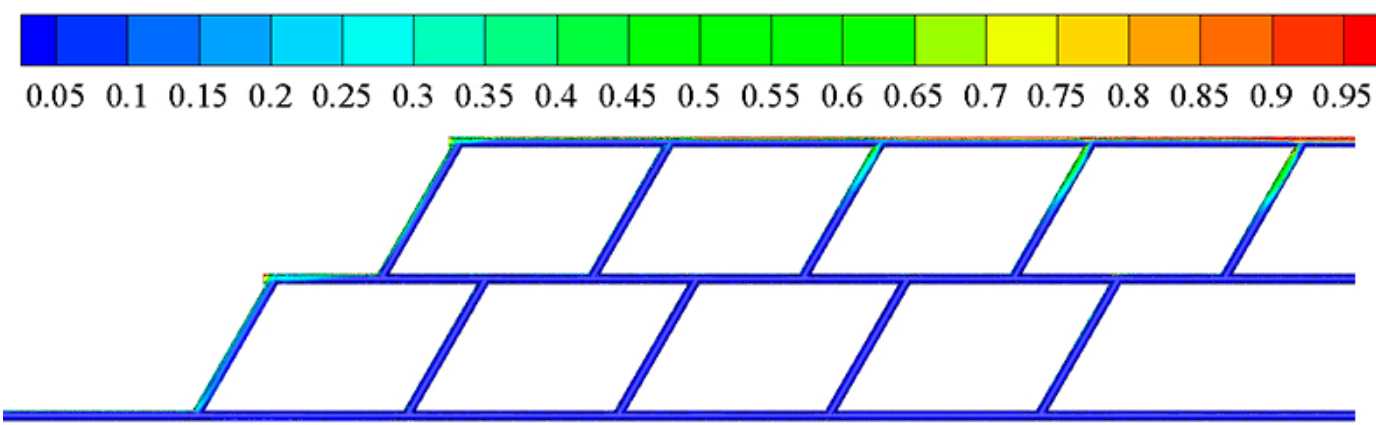

Figure 5. Gas content distribution for the oil droplet size of $1 \mathrm{~mm}$ under inlet $20 \mathrm{~m}^{3} / \mathrm{h}$ flow rate.

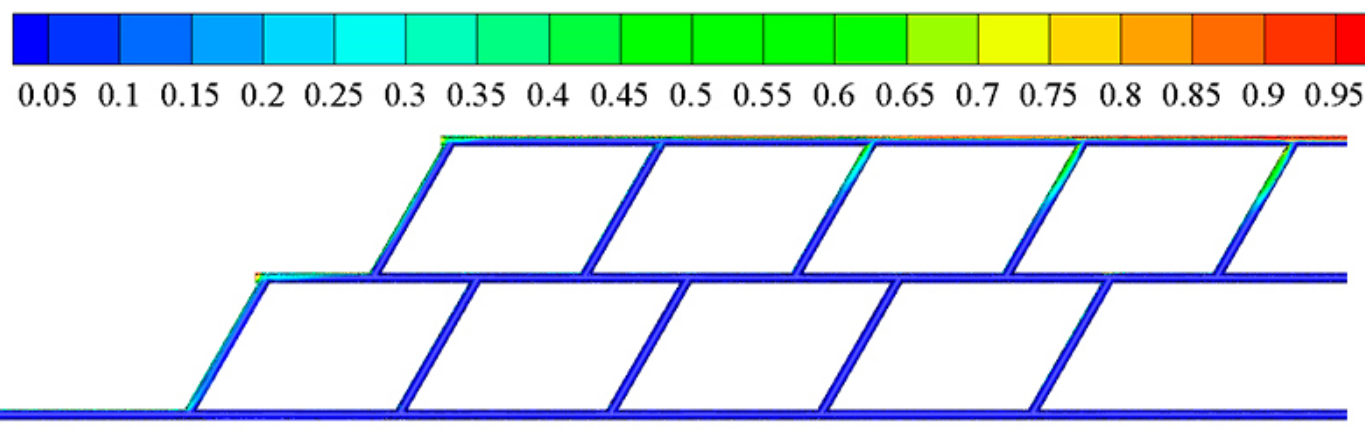

Figure 6. Water content distribution for the oil droplet size of $2 \mathrm{~mm}$ under inlet $20 \mathrm{~m}^{3} / \mathrm{h}$ flow rate.

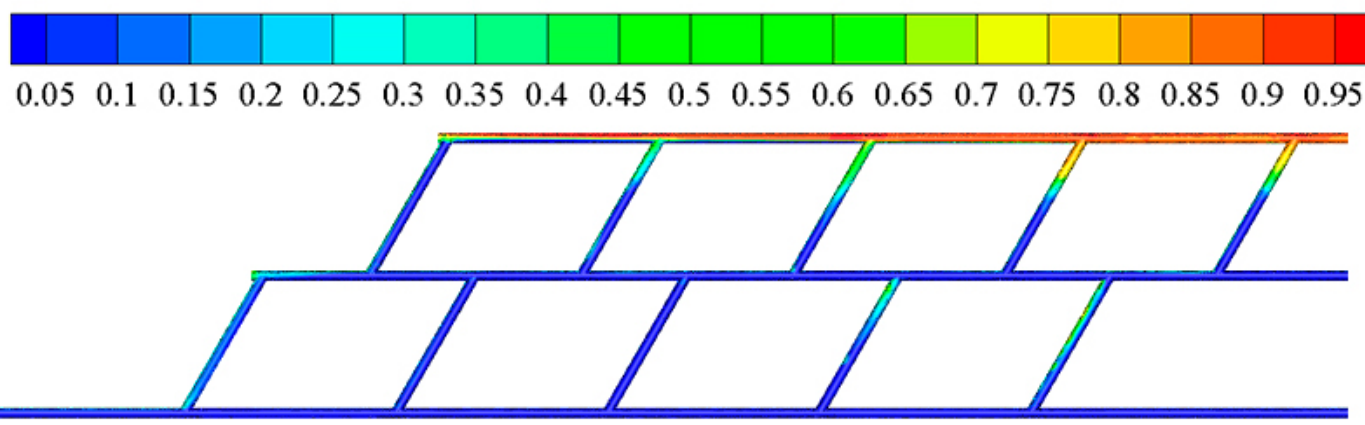

Figure 7. Gas content distribution for the oil droplet size of $2 \mathrm{~mm}$ under inlet $20 \mathrm{~m}^{3} / \mathrm{h}$ flow rate.

Table 3 shows the effect of oil droplet size on the separation performance of multitube T-junction separators with inner diameters of $100 \mathrm{~mm}$ under inlet $50 \mathrm{~m}^{3} / \mathrm{h}$ flow rates. Figures $8-11$ show the corresponding phase distribution in the separator with oil droplet sizes of 1 and $3 \mathrm{~mm}$. The separation performances varied significantly for oil droplet sizes of 1 and $3 \mathrm{~mm}$. The water content at the water 
outlet increased from $94.13 \%$ to $99.64 \%$, and the water content at the oil outlet changed from $37.38 \%$ to $18.43 \%$. However, the separation performance changed slightly for the oil droplet size of 3 and $4 \mathrm{~mm}$. This showed that, as the oil droplet size increased, the water content at the water outlet initially increased and then tended to be stable. Unlike the $50 \mathrm{~mm}$ inner diameter (I.D.) separator, the oil droplet size had little influence on the gas content at the gas outlet when the $100 \mathrm{~mm}$ I.D. separator was used. This was because the large pipe provided sufficient space for gas-liquid separation.

Table 3. Influence of the oil droplet size on the separation performance under inlet $50 \mathrm{~m}^{3} / \mathrm{h}$ flow rate.

\begin{tabular}{|c|c|c|c|c|c|c|c|c|c|}
\hline $\begin{array}{c}\text { Oil } \\
\text { Droplet } \\
\text { Size } \\
(\mathrm{mm})\end{array}$ & $\begin{array}{l}\text { Water } \\
\text { Flow } \\
\text { Rate } \\
\left(\mathrm{m}^{3} / \mathrm{h}\right)\end{array}$ & $\begin{array}{l}\text { Oil } \\
\text { Flow } \\
\text { Rate } \\
\left(\mathrm{m}^{3} / \mathrm{h}\right)\end{array}$ & $\begin{array}{l}\text { Gas } \\
\text { Flow } \\
\text { Rate } \\
\left(\mathrm{m}^{3} / \mathrm{h}\right)\end{array}$ & $\begin{array}{c}\text { Water } \\
\text { Content at } \\
\text { the Water } \\
\text { Outlet }\end{array}$ & $\begin{array}{c}\text { Gas } \\
\text { Content at } \\
\text { the Water } \\
\text { Outlet }\end{array}$ & $\begin{array}{c}\text { Water } \\
\text { Content } \\
\text { at the Oil } \\
\text { Outlet }\end{array}$ & $\begin{array}{c}\text { Gas } \\
\text { Content } \\
\text { at the Oil } \\
\text { Outlet }\end{array}$ & $\begin{array}{c}\text { Gas } \\
\text { Content at } \\
\text { the Gas } \\
\text { Outlet }\end{array}$ & $\begin{array}{c}\text { Water } \\
\text { Content at } \\
\text { the Gas } \\
\text { Outlet }\end{array}$ \\
\hline 4 & 42.27 & 7.73 & 1.55 & 0.9975 & 0.0071 & 0.1111 & 0.0097 & 0.8819 & 0.1181 \\
\hline 3 & 42.27 & 7.73 & 1.55 & 0.9964 & 0.0066 & 0.1843 & 0.0087 & 0.8781 & 0.1033 \\
\hline 1 & 42.27 & 7.73 & 1.55 & 0.9413 & 0.0021 & 0.3738 & 0.0002 & 0.8554 & 0.1207 \\
\hline
\end{tabular}

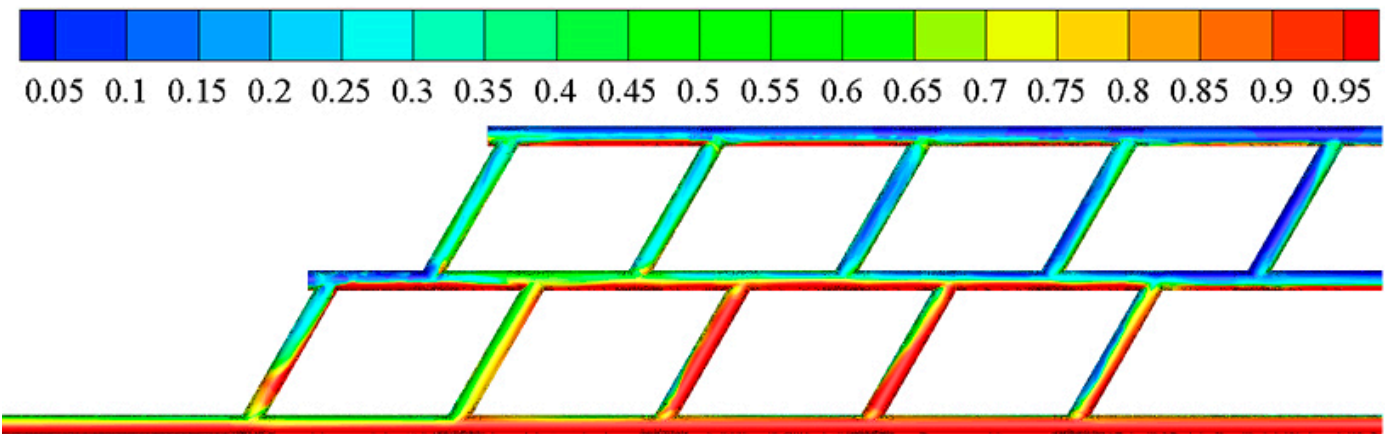

Figure 8. Water content distribution for the oil droplet size of $1 \mathrm{~mm}$ under inlet $50 \mathrm{~m}^{3} / \mathrm{h}$ flow rate.

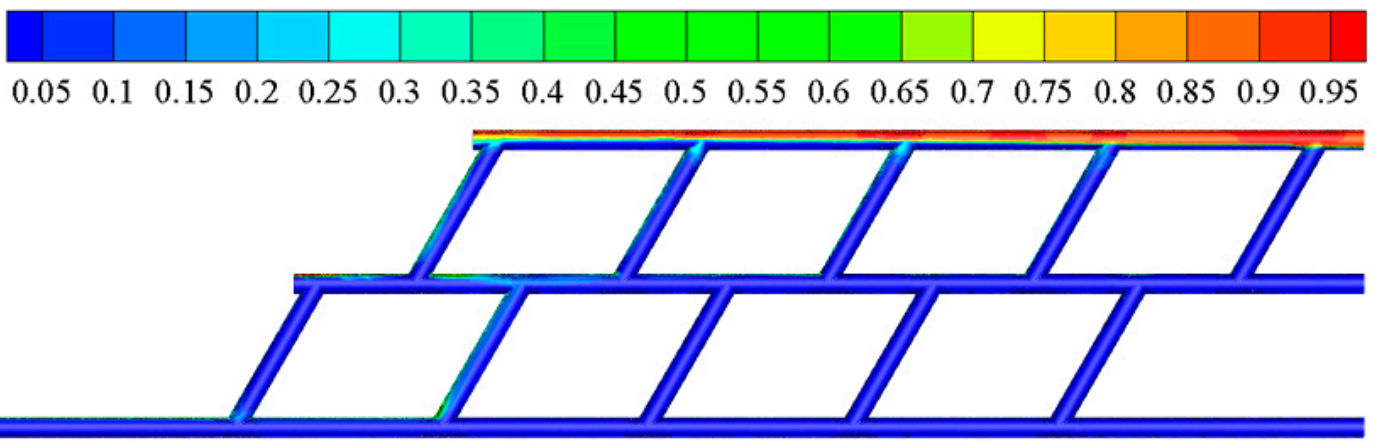

Figure 9. Gas content distribution for the oil droplet size of $1 \mathrm{~mm}$ under inlet $50 \mathrm{~m}^{3} / \mathrm{h}$ flow rate.

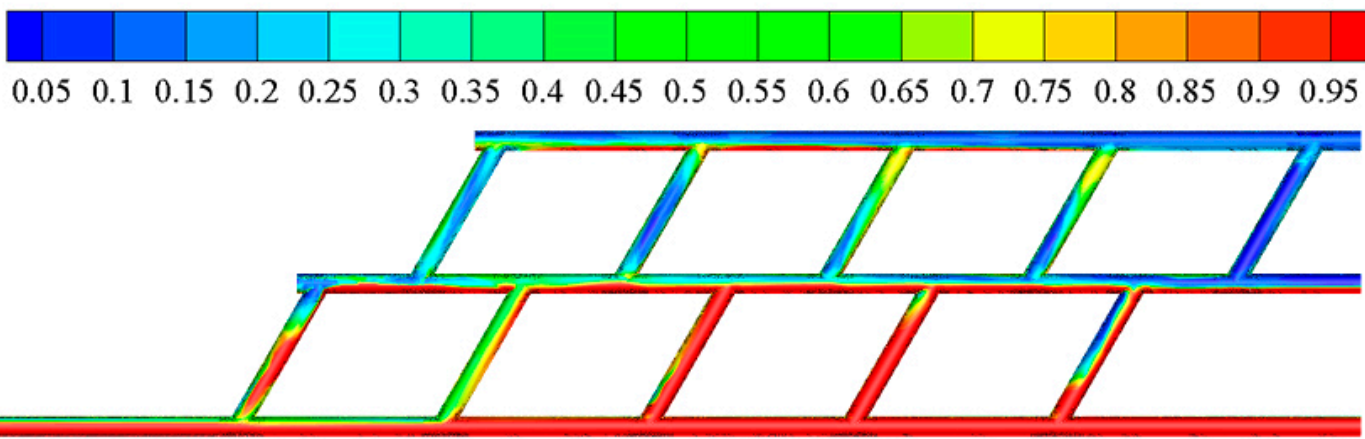

Figure 10. Water content distribution for the oil droplet size of $3 \mathrm{~mm}$ under inlet $50 \mathrm{~m}^{3} / \mathrm{h}$ flow rate. 


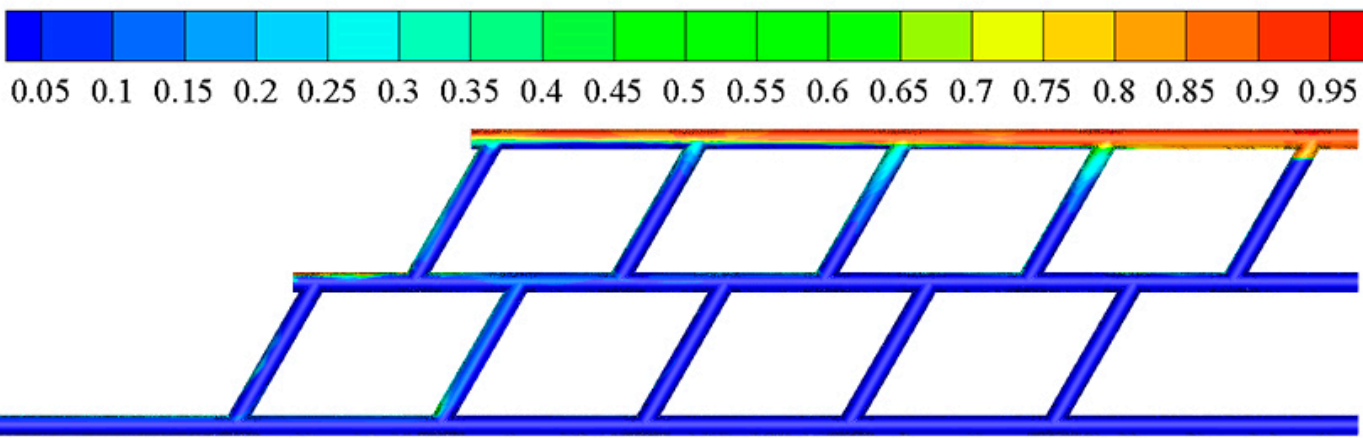

Figure 11. Gas content distribution for the oil droplet size of $3 \mathrm{~mm}$ under inlet $50 \mathrm{~m}^{3} / \mathrm{h}$ flow rate.

\subsection{Effect of the Oil Content on the Separation Performance}

Table 4 shows the effect of oil content on the separation performance of multitube T-junction separators with inner diameters of $50 \mathrm{~mm}$ under inlet $20 \mathrm{~m}^{3} / \mathrm{h}$ flow rates. Figures $12-15$ show the corresponding phase distribution in the separator for the inlet oil content of $15 \%$ and $20 \%$ when the oil droplet size was $1 \mathrm{~mm}$. The oil content has a great influence on the separation performance. When the oil droplet size was $3 \mathrm{~mm}$ and the oil content changed from $20 \%$ to $15 \%$, the water content at the water outlet increased from $92.34 \%$ to $98.16 \%$, and the separation performance was obviously improved. As can be seen from Figures 12 and 14, the inlet flows were the stratified flow. Lower oil content led to a thicker water layer, which made it easier for the oil to move into the lateral arm. This conclusion was also verified by the study about the kerosene and water two-phase flow at a single T-junction conducted by Yang et al. [19]. When the oil droplet size was $1 \mathrm{~mm}$ and the oil content changed from $20 \%$ to $15 \%$, the water content at the water outlet changed from $92.10 \%$ to $94.91 \%$. The water content at the water outlet increased less obviously for the oil droplet size of $1 \mathrm{~mm}$ than the oil droplet size of $3 \mathrm{~mm}$.

Table 4. Phase split results for different oil contents under inlet $20 \mathrm{~m}^{3} / \mathrm{h}$ flow rate.

\begin{tabular}{|c|c|c|c|c|c|c|c|c|c|c|}
\hline $\begin{array}{c}\text { Oil } \\
\text { Content }\end{array}$ & $\begin{array}{l}\text { Oil } \\
\text { Droplet } \\
\text { Size } \\
(\mathrm{mm})\end{array}$ & $\begin{array}{l}\text { Water } \\
\text { Flow } \\
\text { Rate } \\
\left(\mathrm{m}^{3} / \mathrm{h}\right)\end{array}$ & $\begin{array}{c}\text { Oil } \\
\text { Flow } \\
\text { Rate } \\
\left(\mathrm{m}^{3} / \mathrm{h}\right) \\
\end{array}$ & $\begin{array}{l}\text { Gas } \\
\text { Flow } \\
\text { Rate } \\
\left(\mathrm{m}^{3} / \mathrm{h}\right)\end{array}$ & $\begin{array}{c}\text { Water } \\
\text { Content at } \\
\text { the Water } \\
\text { Outlet }\end{array}$ & $\begin{array}{c}\text { Gas } \\
\text { Content at } \\
\text { the Water } \\
\text { Outlet }\end{array}$ & $\begin{array}{c}\text { Water } \\
\text { Content } \\
\text { at the Oil } \\
\text { Outlet }\end{array}$ & $\begin{array}{c}\text { Gas } \\
\text { Content } \\
\text { at the Oil } \\
\text { Outlet }\end{array}$ & $\begin{array}{c}\text { Gas } \\
\text { Content at } \\
\text { the Gas } \\
\text { Outlet }\end{array}$ & $\begin{array}{c}\text { Water } \\
\text { Content at } \\
\text { the Gas } \\
\text { Outlet }\end{array}$ \\
\hline $15 \%$ & 3 & 16.9 & 3.1 & 0.62 & 0.9816 & 0.0105 & 0.2385 & 0.0210 & 0.8965 & 0.1035 \\
\hline $20 \%$ & 3 & 15.876 & 4.124 & 0.62 & 0.9234 & 0.0184 & 0.2596 & 0.0054 & 0.4815 & 0.3083 \\
\hline $15 \%$ & 1 & 16.9 & 3.1 & 0.62 & 0.9491 & 0.0014 & 0.2976 & 0.0014 & 0.4098 & 0.2318 \\
\hline
\end{tabular}

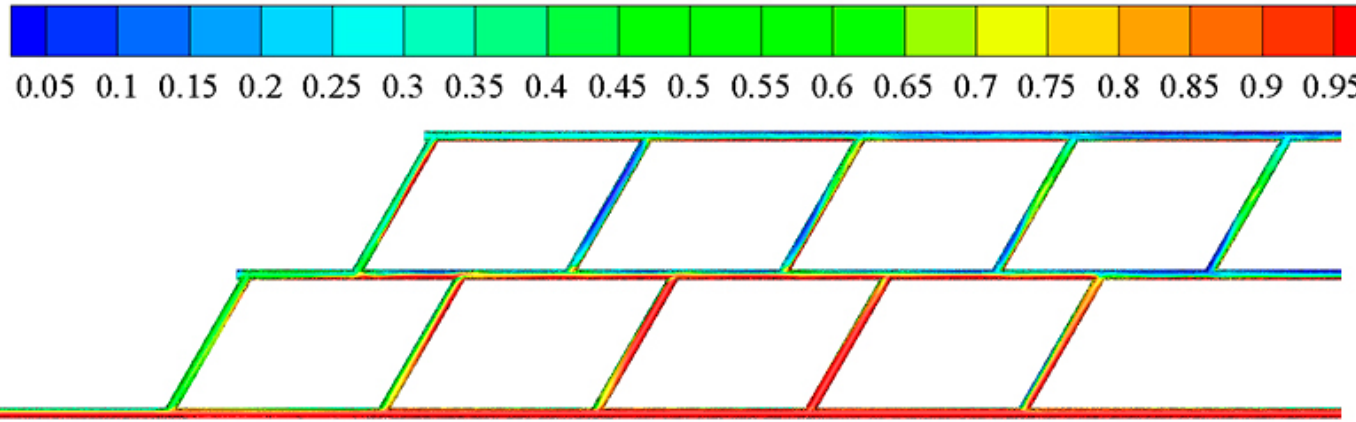

Figure 12. Water content distribution for the inlet oil content of $15 \%$ and the oil droplet size of $1 \mathrm{~mm}$ under inlet $20 \mathrm{~m}^{3} / \mathrm{h}$ flow rate. 

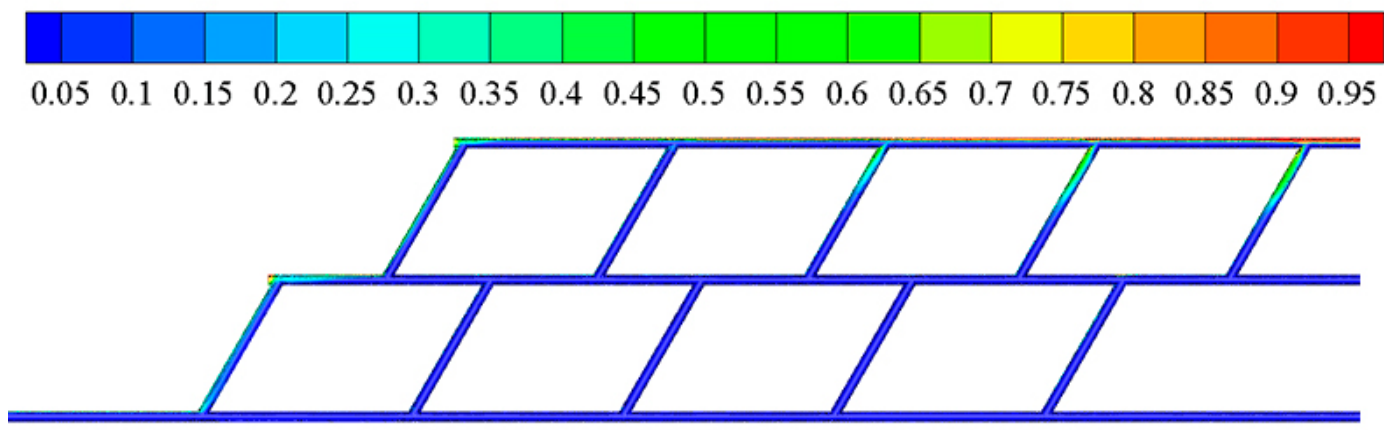

Figure 13. Gas content distribution for the inlet oil content of $15 \%$ and the oil droplet size of $1 \mathrm{~mm}$ under inlet $20 \mathrm{~m}^{3} / \mathrm{h}$ flow rate.
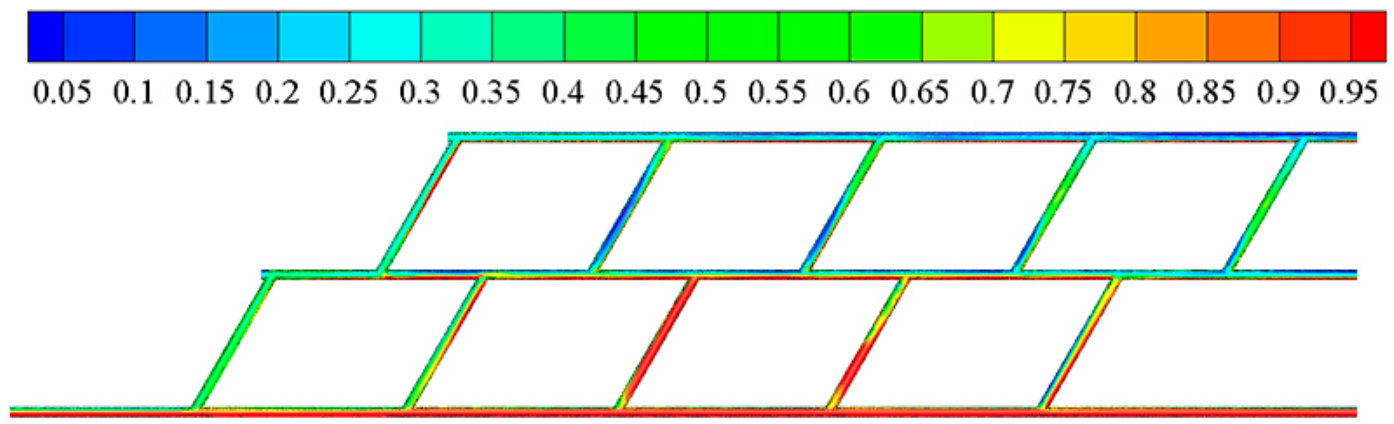

Figure 14. Water content distribution for the inlet oil content of $20 \%$ and the oil droplet size of $1 \mathrm{~mm}$ under inlet $20 \mathrm{~m}^{3} / \mathrm{h}$ flow rate.

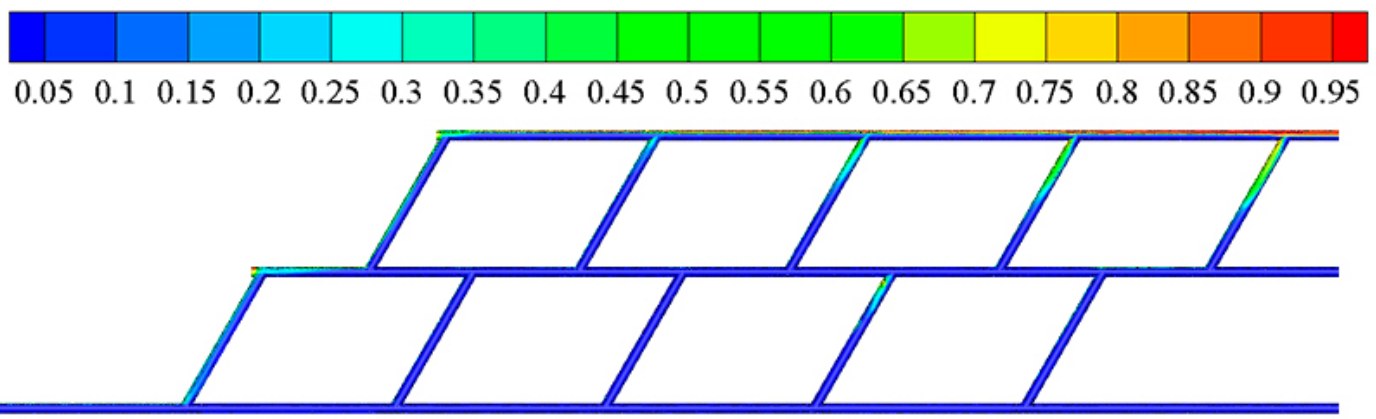

Figure 15. Gas content distribution for the inlet oil content of $20 \%$ and the oil droplet size of $1 \mathrm{~mm}$ under inlet $20 \mathrm{~m}^{3} / \mathrm{h}$ flow rate.

Table 5 shows the effect of oil content on the separation performance of multitube T-junction separators with inner diameters of $100 \mathrm{~mm}$ under inlet $50 \mathrm{~m}^{3} / \mathrm{h}$ flow rates. Figures $16-19$ show the corresponding phase distribution in the separator with oil content of $15 \%$ and $10 \%$. As can be seen, almost pure water can be obtained at the water outlet for different oil content, which was different from the phase split at the multitube T-junction separator with an inner diameter of $50 \mathrm{~mm}$. The inlet velocity was high, owing to the small pipe diameter. The residence time of the incoming liquid in the multitube T-junction separator was short. It became difficult to separate the oil phase from the water phase when the oil content was high, which was similar to the gas-liquid separation results at horizontal T-junctions, as observed by Baker et al. [29]. As can be seen from the gas content distribution, the oil content had little influence on the degassing effect. Under all the conditions, more than $90 \%$ of the gas was discharged from the gas outlet, which met the requirements of degassing. 
Table 5. Phase split results for different oil contents under inlet $50 \mathrm{~m}^{3} / \mathrm{h}$ flow rate.

\begin{tabular}{cccccccccc}
\hline $\begin{array}{c}\text { Oil } \\
\text { Content }\end{array}$ & $\begin{array}{c}\text { Water } \\
\text { Flow } \\
\text { Rate } \\
\left(\mathbf{m}^{\mathbf{3}} \mathbf{h}\right)\end{array}$ & $\begin{array}{c}\text { Oil } \\
\text { Flow } \\
\text { Rate } \\
\left(\mathbf{m}^{\mathbf{3}} / \mathbf{h}\right)\end{array}$ & $\begin{array}{c}\text { Gas } \\
\text { Flow } \\
\text { Rate } \\
\left(\mathbf{m}^{\mathbf{3}} / \mathbf{h}\right)\end{array}$ & $\begin{array}{c}\text { Water } \\
\text { Content at } \\
\text { the Water } \\
\text { Outlet }\end{array}$ & $\begin{array}{c}\text { Gas } \\
\text { Content at } \\
\text { the Water } \\
\text { Outlet }\end{array}$ & $\begin{array}{c}\text { Water } \\
\text { Content } \\
\text { at the Oil } \\
\text { Outlet }\end{array}$ & $\begin{array}{c}\text { Gas } \\
\text { Content the Oil } \\
\text { at } \\
\text { Outlet }\end{array}$ & $\begin{array}{c}\text { Gas } \\
\text { Content at } \\
\text { the Gas } \\
\text { Outlet }\end{array}$ & $\begin{array}{c}\text { Wontent at } \\
\text { the Gas } \\
\text { Outlet }\end{array}$ \\
\hline $15 \%$ & 42.27 & 7.73 & 1.55 & 0.9964 & 0.0066 & 0.1843 & 0.0087 & 0.8781 \\
$10 \%$ & 44.849 & 5.155 & 1.55 & 0.9979 & 0.0073 & 0.1579 & 0.0073 & 0.9157 \\
$5 \%$ & 47.426 & 2.578 & 1.55 & 0.9982 & 0.0048 & 0.2453 & 0.0049 & 0.8871 \\
\hline
\end{tabular}

$\begin{array}{lllllllllllllllllll}0.05 & 0.1 & 0.15 & 0.2 & 0.25 & 0.3 & 0.35 & 0.4 & 0.45 & 0.5 & 0.55 & 0.6 & 0.65 & 0.7 & 0.75 & 0.8 & 0.85 & 0.9 & 0.95\end{array}$

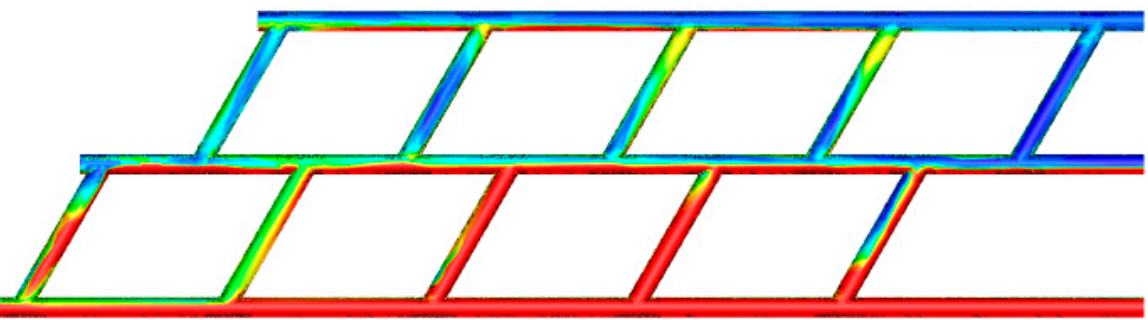

Figure 16. Water content distribution for the inlet oil content of $15 \%$ under inlet $50 \mathrm{~m}^{3} / \mathrm{h}$ flow rate.
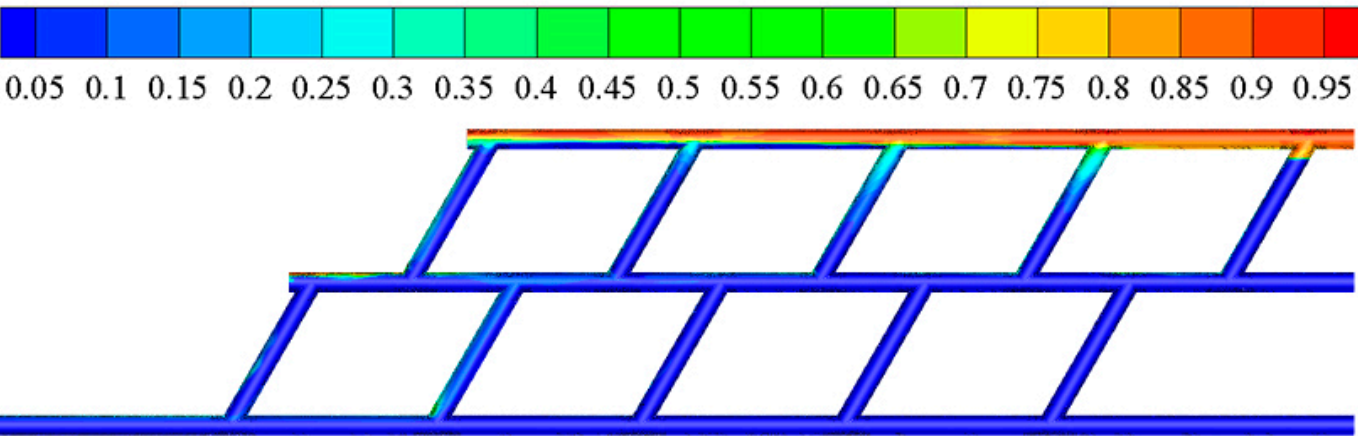

Figure 17. Gas content distribution for the inlet oil content of $15 \%$ under inlet $50 \mathrm{~m}^{3} / \mathrm{h}$ flow rate.

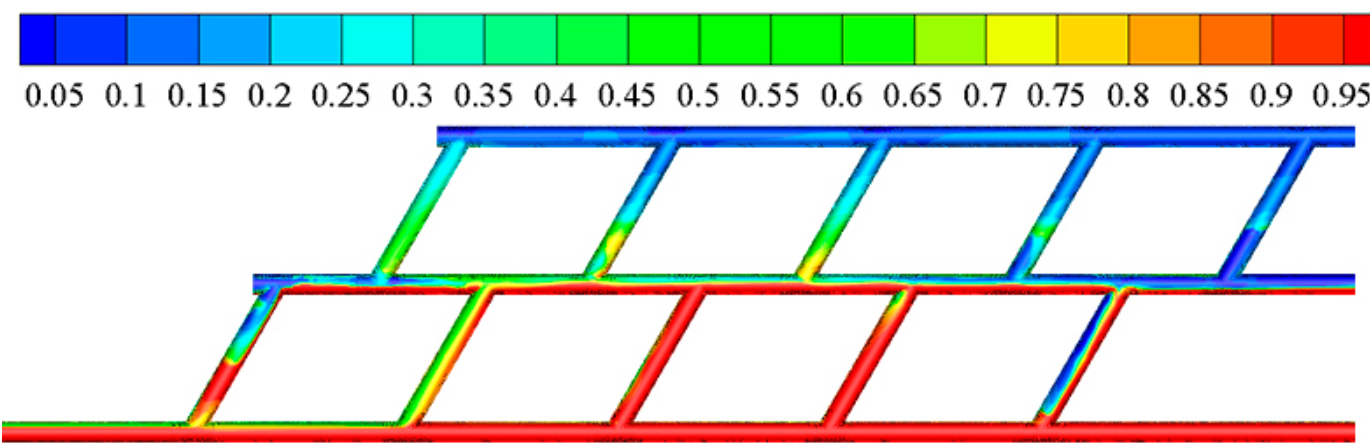

Figure 18. Water content distribution for the inlet oil content of $10 \%$ under inlet $50 \mathrm{~m}^{3} / \mathrm{h}$ flow rate. 

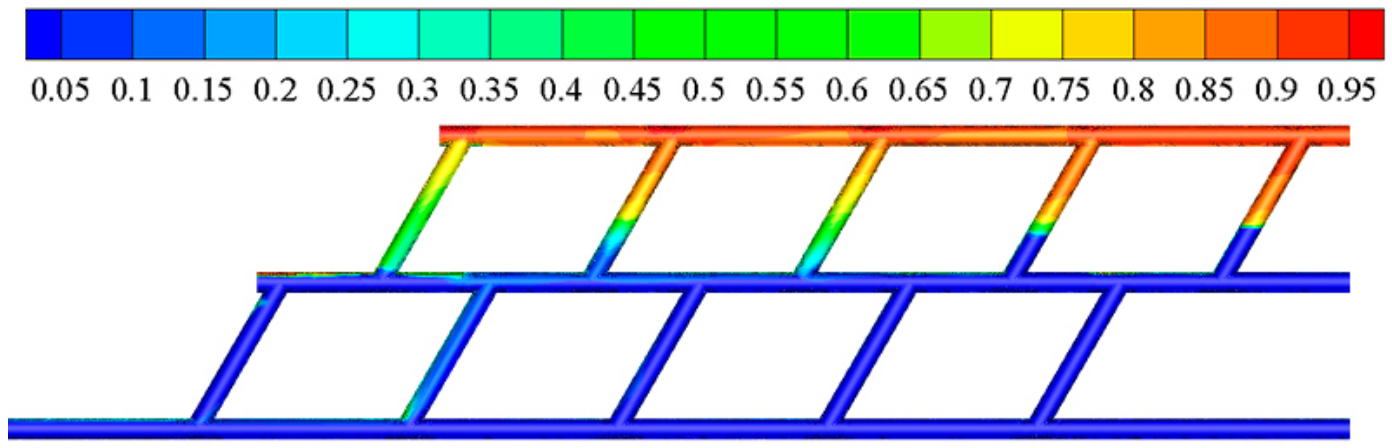

Figure 19. Gas content distribution for the inlet oil content of $10 \%$ under inlet $50 \mathrm{~m}^{3} / \mathrm{h}$ flow rate.

\subsection{Effect of the Gas Content on the Separation Performance}

The remaining inlet mixture flow rates and oil-water ratio were unchanged; the inlet gas content was adjusted to investigate its effect on the separation performance of multitube T-junction separators. Figure 20 shows the variations of the water content at the water outlet and the gas content at the gas outlet with the inlet gas content. As the inlet gas content increased from $10 \%$ to $25 \%$, the water content at the water outlet decreased from $97.63 \%$ to $86.49 \%$, and the gas content at the gas outlet decreased from $91.17 \%$ to $80.17 \%$. Moreover, the oil content at the oil outlet also decreased from $48.81 \%$ to $36.27 \%$. This indicated that the separation performance became worse as the inlet gas content increased. This is because a slip velocity between the gas phase and liquid phase existed, and this slip velocity induced a shear action. As the gas content increased, the shear action enhanced and the carrying capacity of the gas stream improved gradually, as suggested by Yang et al. [30]. Gradually, the gas stream was able to overcome the gravity effect of the liquid phase and carried them upward via the inclined vertical pipe, as can be seen from Figure 21.
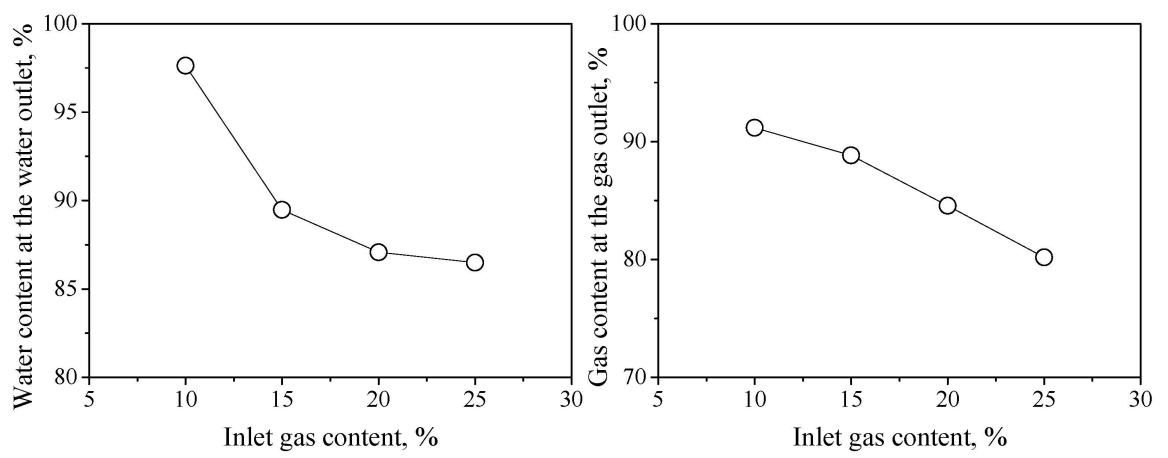

Figure 20. Effect of inlet gas content on the separation performance of multitube T-junction separator.
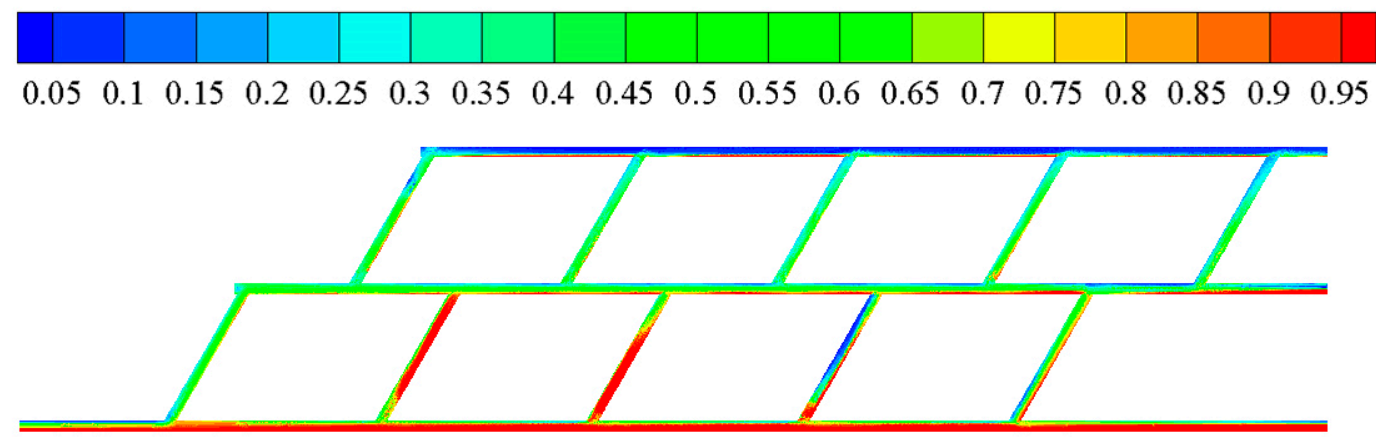

Figure 21. Water content distribution for the inlet gas content of $30 \%$. 


\section{Conclusions}

The mixture model, coupled with the $k-\varepsilon$ turbulent model, was applied for a simulation of the oil-water-gas three-phase flow characteristics in multitube T-junction separators. The separation performance of the separator for different inlet oil droplet size distributions and oil contents was studied. The numerical results showed that, as the oil droplet size increased, the water content at the water outlet initially increased and then tended to be stable. Therefore, it is necessary to increase the oil droplet size through some measures before flowing into the T-junction for separation. For the separator with an inner diameter of $50 \mathrm{~mm}$, the oil content at the inlet had a great influence on the separation performance, and the water-oil separation performance was obviously improved as the oil content decreased. When the separator with an inner diameter of $100 \mathrm{~mm}$ was applied, the oil content had little influence on the water-oil separation performance, owing to the increased residence time. For the separator with an inner diameter of $100 \mathrm{~mm}$, the oil content had little influence on the degassing effect, and more than $90 \%$ of the gas could be discharged from the gas outlet. The separation performance of multitube T-junction separators became worse as the inlet gas content increased. This work indicates that multitube T-junction separators can realize good oil-water-gas separation performance, which proves that T-junction tubes have very good prospects.

Author Contributions: Conceptualization, L.Y.; methodology, L.Y.; software, L.Y.; validation, J.W. and S.L.; formal analysis, J.T.; investigation, J.W.; resources, L.Y.; data curation, J.W.; writing—original draft preparation, L.Y.; writing - review and editing, L.Y.; visualization, J.W.; supervision, L.Y.; project administration, L.Y.; funding acquisition, Y.M. and Y.Z.

Funding: This research was funded by the China Postdoctoral Science Foundation (No. 2019M663242), the Fundamental Research Funds for the Central Universities (No. 19lgpy86) and the Dedicated Fund for Promoting High-Quality Economic Development in Guangdong Province (Marine Economic Development Project) (No. GDOE[2019]A43).

Acknowledgments: Authors gratefully acknowledge Jingyu Xu in the Institute of Mechanics, Chinese Academy of Sciences.

Conflicts of Interest: The authors declare no conflicts of interest.

\section{References}

1. Goh, P.S.; Ismail, A.F.; Ng, B.C.; Abdullah, M.S. Recent progresses of forward osmosis membranes formulation and design for wastewater treatment. Water 2019, 11, 2043. [CrossRef]

2. Halim, A.; Syakinah, N.; Wirzal, M.D.H.; Bilad, M.R.; Nordin, M.; Hadi, N.A.; Faungnawakij, K. Electrospun nylon 6, 6/ZIF-8 nanofiber membrane for produced water filtration. Water 2019, 11, 2111. [CrossRef]

3. Liang, B.; Zhang, G.; Zhong, Z.; Sato, T.; Hozumi, A.; Su, Z. Substrate-independent polyzwitterionic coating for oil/water separation membranes. Chem. Eng. J. 2019, 362, 126-135. [CrossRef]

4. Saieed, A.; Pao, W.; Hewakandamby, B.; Azzopardi, B.J.; Wood, D.A.; Ali, H.M. Experimental investigation on the effect of diameter ratio on two-phase slug flow separation in a T-junction. J. Petrol. Sci. Eng. 2018, 170, 139-150. [CrossRef]

5. Yang, L.L.; Xu, J.Y. An experimental study on gas and liquid separation at Y-junction tubes by pressure control. Sep. Sci. Technol. 2017, 52, 1496-1503. [CrossRef]

6. Wang, L.Y.; Wu, Y.X.; Zheng, Z.C.; Guo, J.; Zhang, J.; Tang, C. Oil-Water two-phase flow inside T-junction. J. Hydrodyn. 2008, 20, 147-153. [CrossRef]

7. Yang, L.L.; Liu, S.; Li, H.; Zhang, J.; Wu, Y.X.; Xu, J.Y. Gas-Liquid flow splitting in T-junction with inclined lateral arm. J. Hydrodyn. 2018, 30, 173-176. [CrossRef]

8. Seeger, W.; Reimann, J.; Müller, U. Two-Phase flow in a T-junction with a horizontal inlet. Part I: Phase separation. Int. J. Multiphas. Flow. 1986, 12, 575-585. [CrossRef]

9. Chisholm, D. Pressure Losses in Bends and Tees During Steam-Water Flow (NEL Report); National Engineering Laboratory: Glasgow, Scotland, 1967.

10. Saba, N.; Lahey, R.T., Jr. Phase separation phenomena in branching conduits. Topical report Dec 78-Dec 81. Rensselaer Polytech. Inst. 1982, 14, 14732094. 
11. Reimann, J.; Seeger, W. Two-Phase flow in a T-junction with a horizontal inlet. Int. J. Multiphas. Flow Part II Press. Differ. 1986, 12, 587-608. [CrossRef]

12. Baker, G.; Clark, W.W.; Azzopardi, B.J.; Wilson, J.A. Transient effects in gas-liquid phase separation at a pair of T-junctions. Chem. Eng. Sci. 2008, 63, 968-976. [CrossRef]

13. He, K.; Wang, S.; Huang, J. The effect of flow pattern on split of two-phase flow through a micro-T-junction. Int. J. Heat Mass Transf. 2011, 54, 3587-3593. [CrossRef]

14. Yang, B.; Su, W.; Deng, S.; Zhao, L.; Lu, P. State-of-Art of branching T-junction: experiments, modeling, developing prospects and applications. Exp. Therm. Fluid. Sci. 2019, 109, 109895. [CrossRef]

15. Hwang, S.T.; Soliman, H.M.; Lahey, R.T., Jr. Phase separation in dividing two-phase flows. Int. J. Multiphas. Flow 1988, 14, 439-458. [CrossRef]

16. Penmatcha, V.; Ashton, P.; Shoham, O. Two-Phase stratified flow splitting at a T-jun. Int. J. Multiphas. Flow 1996, 22, 1105-1122. [CrossRef]

17. Hart, J.; Hamersma, P.J.; Fortuin, J.M.H. A model for predicting liquid route preference during gas-liquid flow through horizontal branched pipelines. Chem. Eng. Sci. 1991, 46, 1609-1622. [CrossRef]

18. Ottens, M.; Hoefsloot, H.C.J.; Hamersma, P.J. Transient gas-liquid flow in horizontal T-junctions. Chem. Eng. Sci. 2001, 56, 43-55. [CrossRef]

19. Yang, L.; Azzopardi, B.J.; Belghazi, A.; Nakanishi, S. Phase separation of liquid-liquid two-phase flow at a T-junction. AIChE J. 2006, 52, 141-149. [CrossRef]

20. Yang, L.; Azzopardi, B.J. Phase split of liquid-liquid two-phase flow at a horizontal T-junction. Int. J. Multiphas. Flow 2007, 33, 207-216. [CrossRef]

21. Saieed, A.; Pao, W.; Ali, H.M. Prediction of phase separation in a T-junction. Exp. Therm. Fluid. Sci. 2018, 97, 160-179. [CrossRef]

22. Chen, J.; He, K.; Huang, J. Study of Phase Splitting at a Micro-T-Junction. Heat Transf. Eng. 2014, 35, 1114-1121. [CrossRef]

23. Wren, E.; Azzopardi, B.J. The phase separation capabilities of two T-junctions placed in series. Chem. Eng. Res. Des. 2004, 82, 364-371. [CrossRef]

24. Yin, J.L.; Li, J.J.; Ma, Y.F.; Wang, D.Z. Numerical approach on the performance prediction of a gas-liquid separator for TMSR. J. Nucl. Sci. Tech. 2017, 8, 1134-1141. [CrossRef]

25. Brennan, M. CFD simulations of hydrocyclones with an air core-comparison between large eddy simulations and a second moment closure. Chem. Eng. Res. Des. 2016, 84, 495-505. [CrossRef]

26. Manninen, M.; Taivassalo, V.; Kallio, S. On the Mixture Model for Multiphase Flow; V.T.T.: Espoo, Finland, 1996; pp. 3-67.

27. Schiller, L. A drag coefficient correlation. Zeit. Ver. Deutsch. Ing. 1933, 77, 318-320.

28. Shao, S.; Li, Y.; Lü, T.; Qi, D.; Zhang, D.; Zhao, H. Removal of emulsified oil from aqueous environment by using polyvinylpyrrolidone-coated magnetic nanoparticles. Water 2019, 11, 1993. [CrossRef]

29. Baker, G.; Clark, W.W.; Azzopardi, B.J.; Wilson, J.A. Controlling the phase separation of gas-liquid flows at horizontal T-junctions. AIChE J. 2007, 53, 1908-1915. [CrossRef]

30. Yang, L.L.; Zhang, J.; Ma, Y.; Xu, J.Y.; Wang, J. Experimental and numerical study of separation characteristics in gas-liquid cylindrical cyclone. Chem. Eng. Sci. 2019, 115362. [CrossRef]

(C) 2019 by the authors. Licensee MDPI, Basel, Switzerland. This article is an open access article distributed under the terms and conditions of the Creative Commons Attribution (CC BY) license (http://creativecommons.org/licenses/by/4.0/). 